\title{
Stereotype and Social Prejudices between Local Communities with the Ex Ambon Refugee Communities in Realizing Social Integration in the City of Baubau
}

\author{
H Amin', W O Arsyiah ${ }^{2}$ \\ ${ }^{1,2}$ Universitas Dayanu Ikhsanuddin, Baubau \\ 1hartiniamin@unidayan.ac.id, ${ }^{2}$ waodearsyiah@unidayan.ac.id
}

\begin{abstract}
This study aimed to is to explain the forms of social stereotypes and prejudices between local communities and ex Ambon refugee communities and the extent to which such stereotypes and prejudices affect the process of social integration that has occurred in the city of Baubau. A qualitative method with a phenomenological approach is used to analyze information obtained from informants. The results showed that the stereotype that developed between the two communities was manifested in the form of individual stereotypes and social stereotypes. While the prejudice that occur between the two communities are divided into four type, namely 1) not prejudice and non discrimination, 2) not prejudice but discriminatory, 3) prejudice but not discriminatory, and 4) prejudice and discriminatory. The stereotypes and prejudices that exist between these two communities in the short time are relatively not an obstacle to the social processes that have formed but in the long run can be a trigger for social disintegration in these two communities.
\end{abstract}

Keywords: Stereotypes And Prejudices, Local Communities And Ex Ambon Refugees

\section{INTRODUCTION}

At the time of the mass riots in Ambon in 1999 around 160.000 migrants from Buton had return to Buton as refugees. This amount is equivalent to $35 \%$ of the population in the city of Baubau which in the year of arrival of the refugees was still in Buton Regency. The arrival of refugees directly brought various kinds of impacts on the local community. Changes that occur quickly, unexpectedly and unplanned cause confusion and unpreparedness for both local communities and refugees. A sudden increase in population, attitudes and behavior trigger the presence of social stress in local communities and refugees.

Over time after two decades from 1999 to 2019 the process of social relations between local communities and ex Ambonese refugee community in the city of Baubau showed the dynamics of an associative as well as dissociative pattern of relations, in the first decade an adaptation process that often presents friction due to differences in character, culture, values and norms so that triggering the presence of several cases of conflict between communities there have been recorded conflicts with local communities such as conflicts with Lipu and Wameo Communities. In the second decade there was an acculturation process, cooperation and acceptance process from each community. Nevertheless there are still some potential that can 
trigger divisions between the two communities related to attitudes and behaviors that appear in the stereotypes, distances and prejudices that still color the process of interaction between these two communities[1]

The ex Ambonese refugees judging from their history, generally came from Buton. Thay came to Maluku in the era dutch Indies in the 1800. The Butonese in Ambon can be divide into 2 groups : those born in Ambon and those born in Buton but continuing their education or becoming migrants in Ambon. People who have lived for decades in Ambon no longer know their native culture anymore, covered by the culture of Ambon where they live. The character and behavior of the Ambonese community, especially the local ethnic groups, is a tendency to play for fun, like to group, make gangs, and play music. This behavior can be seen in their daily lives, both in their own area and overseas[2]. If streotypes and prejudices between communities are almost always related to issues of race and religion this does not apply to local communities and ex Ambon refugee communities in the city of Baubau because their backgrounds religions and ethnic tend to be the same.

Potential conflicts between local communities and ex Ambon refugee are triggered by the persistence of perceptions, stereotypes and social prejudices that tend to be negative, differences in values and culture adopted by each community and settlement segregation in the sense of settlement patterns that do not blend into potential which can threaten the process of social integration between these communities. This research is a continuation of previous research conducted by Amin in 2011. It is interesting to know how the attitudes and behavior of these two communities in the last eight (8) years, whether streotypes, prejudices and social distance are still potentials that lead in the split or even become a potential integration.

This research is important because there is a lack of research on stereotypes and prejudices or about social behavior between local communities and ex Ambon refugee communities. Research on the relationship between Maluku refugees and local residents in North Sulawesi, which provides a description of stereotypes and prejudices has been carried out for quite some time, around 2004 by Christopher Duncan[3] in the same year in a different location, precisely in Boneoge Blair Palmer also conducted research on the overseas Buton who returned to Buton after the 1999-2002 Maluku conflict. A research specifically studying the self perception of ex Ambon refugees in Kadolokatapi subdistrict was conducted by Ode Mussaing in 2018[4]

Other studies focusing on studies on interactions between migrants and local communities were carried out by Dewi Anggraini on the ethnic Tator and Tolaki in Kolaka Southeast Sulawesi[5] Alfarabi on the Malay ethnic and Migrant ethnic in Pekanbaru Riau[6] Rajab Ali on the Tolaki and Ethnic Muna on the Unhalu Campus[7] Dadan Iskandar about conflicts between madurese and Dayak ethnic migrants in West Kalimantan[8] Ahmad Sihabudin about social prejudice and effectiveness of communication between Baduy Dalam and Baduy Luar ethnics[9]

Similar reserach tends to explain stereotypes and prejudices between two communities that differ in terms of ethnicity or religion, including research on stereotypes and prejudices between ethnic Chinese and ethnic Bugis conducted by Juditha which explains that there are several assessments that tend to be negative between ethnic groups related to character, attitudes and behavior which is different in terms of culture and which is triggered by mastery in the economic, legal and government sectors[10] is not much different from Juditha in Lampe and Anriani is research on the Kaili ethnic and the Bugis Ethnic also explains if the economic inequality factor, differences in character and language (accent) became the cause of the emergence of strereotypes and prejudices[11] besides that Murdianto in his research on prejudice between ethnic Madura and Chinese claimed that the stigma attached to each ethnic 
group was inseparable from a series of past events related to the political situation from the colonial era to the period new order[12] Hernawan in his research on religious prejudice in West Java stated that social prejudice between religious groups occured due to lack of understanding of religious events and differences in position in social and economic structures[13]

Research conducted by Adelina, Hanurawan and Suhanti found that the prejudice and discrimination of Javanese and East Nusa Tenggara ethnic students arose from excessive ethnocentrism as an accumulation of in-group and out-group categorization processes or "us" and "them" between students Javanese origin to students from East Nusa Tenggara [14] Some of studies above illustrates if stereotypes and prejudices that occur both between ethnic and community have gone through a long process, many factors trigger in terms of culture and structure and have an impact on the presence of conflict that can damage the process of integration of the Indonesian nation which is indeed diverse.

\section{RESEARCH METHOD}

This study uses a descriptive qualitative method with a phenomenologycal approach in which researchers conduct in-depth analysis of information obtained directly from informants through careful investigation of an event, both individual and group activities and then interpret the reality obtained as-is through interactive techniques. Data collection, data reduction, data presentation and drawing conclusions are carried out in the data analysis stage. Purposive sampling becomes a technique used to obtain data and information. [15] The informants ot this study consisted of local people and ex Ambon Refugee.

\section{RESULTS AND DISCUSSION}

In this section the author will present the results of an analysis of the forms of stereotypes and prejudices between the local community and the ex Ambon refugee community in Kelurahan Kadolokatapi. before explaining further about the field findings, a brief descpription of the research location will be provided. Kadolokatapi urban village is one of the areas that has the most number of Ambon refugees from all areas in the city of Baubau. At the time of arrival the number of Ambonese refugees living this village far exceeded the number of local residents, which amounted to 2.571 people while the local population only amounted to 1.653 people [1]. Until now there are settlement pockets of these ex Ambonese refugees scattered in 3 RW namely; Bukit Selamat, Jabal Rahmah and Bukit Sari Permai in addition there are also some ex refugee families who living mingling with the local community.

This research is a follow-up study from a study in 2011 by Amin[1] previous research focused more on the dynamics of social interaction between local communities and ex Ambon refugee community in general by focusing research on the potential conflict events or group. Current research focuses more on potential conflicts in the form of stereotypes, social dictance and social prejudice. Interactions between local communities and ex Ambon refugee have so far been running normally and tend to lead to good social relations, especially with ex Ambon Refugees living mingling with local communities. Based on the results of interviews with several local informants about the negative stigma that had been pinned on ex Ambonese Refugees in previous studies the developing streotypes were negative now tend to be positive. The following is an interview excerpt from the housewife HW informant :

Saya tidak lagi menganggap mereka sebagai orang-orang yang suka menang sendiri dan suka bikin onar, tetapi ini hanya untuk mereka yang tinggal di lingkungan ini saja, 
kalau di Bukit Selamat saya tidak tau karena mungkin saja masih ada tapi itu hanya orang- orang tertentu saja karena orang lokal juga tidak semua baik"

The HYT informant of a stall owner added :

Tidak ada lagi istilah pengungsi, orang Ambon, karena mereka sudah lama disini, mereka sudah jauh berubah, memang bahasanya sedikit kasar tetapi sepertinya itu sudah kebiasaan yang sulit mereka ubah, yang penting saat ini hubungan dengan mereka sangat baik.

Slightly different from the information YH informants who work in the same place stated that: Di tempat saya bekerja kadang pegawai yang paling banyak protes dan banyak bicara itu orang dari mereka, mungkin karena gaya berbahasa yang kasar dan menggunakan bahasa Ambon yang kadang membuat saya jengkel juga, sudah lama di Baubau tapi masih menggunakan bahasa Ambon

MJ informants further disclosed that :

Saya masih menganggap mereka sebagai pengungsi karena masih suka mencari cari bantuan membawa nama pengungsi dan masih menggunakan bahasa Ambon padahal mereka sudah lama di Baubau, mereka juga susah diatur, sombong dan ingin menang sendiri”,

The interview excerpt above illustrates the generalization of an individual by drawing conclusions about the characteristics of others based on subjective categories that are cognitive that originate from personal experience. Experience that has formed continously over the years can change stereotypes that previously tended to be socially inherent negative stigma in the sense that assessments given were given comprehensively to almost all ex Ambonese Refugee communities now turned into personal stereotypes.

However, even though the negative stigma has decreased, social distance has not yet completely disappeared, almost all informants expressed readiness to make ex Ambonese Refugees part of the family (relationships formed by marriage). Even though the older generation tends to accept it in the sense that if it is fate, it certainly cannot be denied, but for the younger generation it tends to refuse to have a life partner of ex Ambonese refugees by reason of harsh language, harsh character, being fussy and not knowing local culture is a cause for avoid relationships formed by marriage.

The above condition shows that if the stereotype between the two communities is no longer a trigger that can be cause of the emergence of divisions between communities because each party is trying to build a good relationship between one another, each community has begun to accept and adapt to diffreneces that exists between them. Those who have personal problems from each community will choose attitudes and behaviors to avoid problems by not communicating at all.

The prejudices and stereotypes that emerge from these two communities are sourced from the shared knowledge and experience of the local community about the bloody conflict in 2003 involving refugees from Ambon and the local population who provided psychological shocks to the local communty, remembering throughout history since Indonesia's independence Buton was an area safe which has never once occurred a bloody conflict between regions that claimed lives.

In addition to the shared memory of the bloody conflict, local residents are also disappointed with the ex refugees, who until now still continue to expect help from the government, even though many local people also need help. Initially the local community still considered it as something natural but it became a frustration for the local community when the ex refugees returned to Ambon to get the same assistance there and there were even refugees who sold houses of assistance from the government to return to Ambon. 
One SHR informant stated :

Keberadaan para eks pengungsi Ambon berdampak positif sekaligus negatif. Positifnya di kelurahan ini menjadi ramai tetapi negatifnya lebih banyak karena pengaruhnya tidak terlalu baik terutama dari segi berbicara yang suka memaki dan kasar belum lagi sikap menganggap rendah orang lain dan sok jago

The informant from ex refugee gave a different statement :

Kami sudah lama berada disini, kami merasa sudah menjadi bagian dari wilayah ini, hubungan kami dengan warga lokal cukup baik. Kalau dari segi bahasa yang kasar memang kami akui, mungkin karena sudah jadi kebiasan sehari-hari kami, gaya berbahasa seperti itu mungkin bagi orang lokal dianggap kasar tetapi sebenarnya maksud kami bukan untuk berbicara kasar. Saya merasa orang lokal yang sombong dan tidak menghargai orang lain. Tapi ini hanya orang-orang tertentu saja.

Furhermore one of the informants from ex Ambonese refugees BP alsa said :

Sulit untuk mengikuti budaya orang Buton meski nenek moyang kami juga dari Buton, seperti kebiasaan ritual haroa untuk semua hal dalam kehidupan masyarakat Buton sama sekali tidak ada kebiasan itu di Ambon, jadi saya tidak melakukan itu meski saya sudah tingga puluhan tahun disini.

A different matter was conveyed by YG informants as village officials stating that :

Kalau dilihat secara karakter memang sepertinya berbeda dari segi karakter. Sederhananya orang lokal cenderung lebih sopan dan lebih penurut dalam mengikuti perintah dan arahan ketimbang para eks pengungsi, biasanya yang sulit diatur itu eks pengungsi yang tinggal di Bukit Selamat. Pemberian layanan kepada masyarakat mempunyai mekanisme sendiri yang cukup prosedural yang bisa jadi dianggap sebagai perbedaan pelayanan antar orang lokal dengan orang pendatang, padahal semuanya ada skala prioritas, kebutuhan mendesak dan dirasa penting akan diutamakan.

The description above suggests that each community is equally prejudiced and also gives stereotypes to each other and becomes invalid because it tends to be reduced or generalized as awhole even though it is not necessarily prejudice and stereotype that applies to everyone because after all in every community there certainly consists of a collection various kinds of characters and types of people who have their own characteristics. The experience of getting different services when dealing with government raises negative prejudice.

The prejudices that occur between these two communities are divided into four types namely 1). Prejudice and non-discrimination, this condition occurs in the older generation who tend to accept all differences and consider it as a natural thing, 2). Unprejudiced but discriminatory, this happens to groups adolescents who do not have experience or memories of conflict events that have occurred but are due to social experiences in the school environment or friendship, cursing and abusive language habits cause discrimination in friendship, 3). Prejudiced but not discriminatory, appearing from parties who only get information negative from other people not directly or gain experience just by seeing disputes that do not involve him directly and 4). Prejudiced and discriminatory tend to occur in people who have had direct confrontations so what to the unpleasant events that have occured have been the cause of discriminating attitudes and have chosen to reduce opportunieties for direct interaction. Stereotypes and prejudices that exists between these two communities in the short term are relatively not yet an obstacle to the process of social integration that has been formed but in the long run can be a trigger for the emergence of social disintegration in these two communities. 


\section{CONCLUSIONS}

The stereotype and prejudice between the local community and ex Ambonese refugee community came as an accumulation of knowledge and experiences of living together within two decades of Ambon riots. Years of continous experience can change the stereotypes and prejudices of the previous ten (10) years which tend to be socially inherent negative stigma in the sense that judgments are given in a comprehensive manner to almost all members of each community, within ten (10) the second year has turned into a personal stereotype. Social relations betwen the two communities run well and lead to cooperation, although the existing stereotypes and prejudices do not have the potential to threaten the process of social integration, the existence of social distance between communities is still one of the causes of the emergence of new stereotypes and prejudices in the future, especially for young generation from both communities.

\section{REFERENCES}

[1] H. Amin, "Dinamika Relasi Sosial Antara Komunitas Lokal Dengan Komunitas Eks Pengungsi Ambon (Analisa Tentang Potensi dan Resolusi Konflik di Kota Baubau)," Akademika, vol. X No.3, pp. 279-288, 2013.

[2] B. Palmer, "Migrasi dan Identitas: Perantau Buton yang Kembali ke Buton Setelah Konflik Maluku 1999-2002,” J. Antropol. Indones., vol. 74, pp. 94-109, 2004.

[3] C. R. Duncan, "Tamu tak Diundang: Hubungan antara Pengungsi Maluku dan Penduduk Lokal di Sulawesi Utara," Akademika, vol. 74, pp. 48-58, 2004.

[4] O. L. adjid Mussaing, A. Tenri, and H. Amin, "Prasangka Sosial (Studi tentang Persepsi Diri Masyarakat Eks Pengungsi Ambon di Kelurahan Kadolokatapi Kecamatan Wolio Kota Baubau)," 2018.

[5] D. Anggraini, "Interaksi Sosial Orang Tanah Toraja Pada Masyarakat Lokal di Kabupaten Kolaka,” J. Kanal, vol. 2, no. 1, pp. 1-16, 2013.

[6] Alfarabi, A. Venus, N. A. Syafirah, and N. efni Salam, "Rekonstruksi Stereotip Negatif Etnik Melayu," J. Manaj. Komun., vol. 3, no. 2, pp. 131-141, 2019.

[7] R. Ali, E. S. Indrawati, and A. M. Masykur, "Hubungan Antara Identitas Etnik Dengan Prasangka Terhadap Etnik Tolaki Pada Mahasiswa Muna di Universitas Haluoleo Kendari Sulawesi Tenggara," J. Psikol. Undip, vol. 7, no. 1, pp. 18-26, 2010.

[8] D. Iskandar, "Identitas Budaya Dalam Komunikasi Antar Budaya: Kasus Etnik Madura dan Etnik Dayak," J. Masy. dan Budaya, vol. 6, no. 2, pp. 119-140, 2004.

[9] A. Sihabudin and S. Amirudin, "Prasangka Sosial dan Efektivitas Komunikasi Antarkelompok," 2008.

[10] C. Juditha, "Stereotip dan Prasangka dalam Konflik Etnis Tionghoa dan Bugis Makassar," J. ilmu Komun., vol. 12 nomor 1, no. 25, pp. 87-104, 2015.

[11] I. Lampe and A. B. Haslinda, "Stereotipe , Prasangka Dan Dinamika Antaretnik," J. Penelit. Pers Dan Komun. Pembang., vol. 20, no. 1, pp. 17-32, 2017.

[12] Murdianto, "Stereotipe, Prasangka dan Resistensinya ( Studi Kasus pada Etnis Madura dan Tionghoa di Indonesia )," J. Qalamuna, vol. 10, no. 2, pp. 137-160, 2018.

[13] W. Hernawan, "Prasangka Sosial Dalam Pluralitas Keberagamaan di Kecamatan Cigugur Kabupaten Kuningan Jawa Barat,” J. Sosiohumaniora, vol. 19, no. 1, pp. 77 85, 2017.

[14] F. Adelina, F. Hanurawan, and I. yasminum Suhanti, "Hubungan Antara Prasangka Sosial dan Intensi Melakukan Diskriminasi Mahasiswa Etnis Jawa Terhadap 
Mahasiswa Yang Berasal Dari Nusa Tenggara Timur,” J. Sains Psikol., vol. 6, no. 1, pp. 1-8, 2017.

[15] E. Kuswarno, Fenomenologi, Metode Penelitian Komunikasi KOnsepsi, Pedoman dan Contoh penelitiannya, April. Bandung: Widya Padjadjaran, 2009. 